\title{
Rancang Bangun Multilevel Boost Converter Untuk Catu Daya Motor Arus Searah Pada Kendaraan Listrik Berbasis Mikrokontroler
}

\author{
${ }^{1}$ Noer Soedjarwanto, ${ }^{2}$ Endah Komalasari, ${ }^{3}$ Venus Asadilla \\ Jurusan Teknik Elektro, Fakultas Teknik, Universitas Lampung \\ J1. Prof. Sumantri Brojonegoro No. 1 Bandar Lampung 35145 \\ e-mail: noersoedjarwanto@gmail.com
}

Intisari - Rangkaian multilevel boost converter memiliki prinsip kerja yang sama dengan boost converter konvensional namun rasio tegangan keluarannya lebih tinggi. Dimana tegangan keluaran dari multilevel boost converter ini akan digunakan sebagai catu daya untuk mengendalikan kecepatan putar motor arus searah (MAS). Kemudian akan dilakukan perbandingan antara tegangan keluaran multilevel boost converter dengan boost converter konvensional yang digunakan sebagai catu daya MAS. Pada penelitian ini nilai tegangan keluaran multilevel boost converter saat dihubungkan pada MAS dengan duty cycle $20 \%$ yaitu 80,3 volt dan MAS sudah mulai berputar dengan kecepatan $350 \mathrm{rpm}$. Sementara tegangan keluaran boost converter konvensional sebesar 39,4 volt namun MAS belum dapat berputar pada duty cycle $20 \%$ dan tegangan masukan yang sama yaitu 12,3 volt. Kemudian dilakukan penambahan beban MAS pada pengujian multilevel boost converter. Dimana semakin berat beban pada MAS maka torsinya akan meningkat. Dengan demikian perangkat multilevel boost converter dapat digunakan sebagai catu daya MAS untuk kendaraan listrik.

Kata kunci: Multilevel boost converter, boost converter, motor arus searah

Abstract - Multilevel boost converter circuit has the same working principle with conventional boost converter. Hence, the ratio of its output voltage is higher that will be used as power supply for controlling the rotational speed of MAS. Then, there will be comparison among the output voltage of multilevel boost converter and conventional boost converter which will be used as power supply of MAS. On this research, the output voltage value of multilevel boost converter which is connected with MAS at the duty cycle $20 \%$ is 80,3 volt. Furthermore, it had rotated at the speed of $320 \mathrm{rpm}$. Meanwhile, the output voltage of boost converter conventional is 39,4 volt. On the contrary, MAS can not rotated at the duty cycle of $20 \%$ with the same input voltage that will be 12,3 volt. Then, it will be added with load of MAS for multilevel boost converter testing. While the load of MAS is heavier, its torque will be increased too. Therefore, multilevel boost converter device can be used as power supply of MAS for electric vehicles.

Keywords : Multilevel boost converter, boost converter, direct current motor

\section{PENDAHULUAN}

Pada saat ini penggunaan kendaraan bermotor di Indonesia sangatlah pesat dengan semakin bergantungnya masyarakat pada kendaraan pribadi sebagai penunjang aktivitas seharihari. Oleh karena itu diperlukan suatu alternatif dari kendaraan bermotor untuk mengurangi konsumsi BBM dan pencemaran udara di Indonesia. Salah satu alternatif tersebut adalah mobil listrik karena merupakan kendaraan tanpa emisi atau tidak memiliki gas buang. Dalam pengoperasiannya mobil listrik membutuhkan mesin listrik, salah satunya yaitu Motor Arus Searah (MAS).

Hal yang perlu diperhatikan selanjutnya adalah alat yang digunakan untuk mengendalikan kecepatan putar dari MAS.
Permasalahannya tegangan masukan yang diperlukan MAS lebih tinggi dibanding tegangan keluaran dari baterai sehingga konverter dc-dc dibutuhkan sebagai penyedia tegangan searah yang besarannya sesuai dengan permintaan beban. Maka dalam penelitian ini akan dirancang konverter dc-dc yang mana tegangan keluarannya dapat dikendalikan sesuai kebutuhan MAS agar dapat menggerakkan kendaraan.

\section{STUDI PUSTAKA}

\section{A. Motor Arus Searah}

Motor Arus Searah (MAS) merupakan perangkat elektromagnetis yang mengubah energi listrik menjadi energi mekanik. MAS memerlukan suplai tegangan searah pada kumparan medan untuk diubah menjadi energi mekanik [2]. 
MAS dapat dibedakan menjadi dua jenis berdasarkan sumber penguat arus magnetnya yaitu motor dengan penguat terpisah dan penguat sendiri. Pada motor penguat sendiri terdiri lagi dari MAS Seri, MAS Shunt, MAS kompon panjang dan MAS kompon pendek. Dalam penelitian ini digunakan MAS seri. MAS seri terdiri dari medan seri yang dibuat dari sedikit lilitan kawat besar yang ihubungkan seri dengan jangkar. Jenis motor ini mempunyai karakteristik torsi start dan kecepatan variabel yang tinggi, ini berarti bahwa motor dapat start atau dapat menggerakkan beban yang sangat berat, tetapi kecepatan akan bertambah kalau beban turun dari sedikit lilitan kawat besar yang dihubungkan seri dengan jangkar. Jenis motor ini mempunyai karakteristik torsi start dan kecepatan variabel yang tinggi, ini berarti bahwa motor dapat start atau dapat menggerakkan beban yang sangat berat, tetapi kecepatan akan bertambah kalau beban turun pada kumparan medan untuk diubah menjadi energi mekanik.

MAS dapat dibedakan menjadi dua jenis berdasarkan sumber penguat arus magnetnya yaitu motor dengan penguat terpisah dan penguat sendiri. Pada motor penguat sendiri terdiri lagi dari MAS Seri, MAS Shunt, MAS kompon panjang dan MAS kompon pendek. Dalam penelitian ini digunakan MAS seri. MAS seri terdiri dari medan seri yang dibuat dari sedikit lilitan kawat besar yang ihubungkan seri dengan jangkar. Jenis motor ini mempunyai karakteristik torsi start dan kecepatan variabel yang tinggi, ini berarti bahwa motor dapat start atau dapat menggerakkan beban yang sangat berat, tetapi kecepatan akan bertambah kalau beban turun

\section{B. Boost Converter}

Boost converter merupakan koverter dcdc yang berfungsi untuk mengubah tegangan masukan yang rendah ke tegangan keluaran yang tinggi (penaik tegangan). Konverter ini bekerja secara periodik saat saklar terbuka dan tertutup. Kemampuan boost converter untuk menaikan tegangan $\mathrm{dc}$ berkaitan dengan prinsip switch duration (ton dan toff switch).

Saat saklar atau switch mosfet pada kondisi tertutup (ton), terjadi hubung singkat sehingga arus akan mengalir ke induktor kemudian menuju sumber kembali, sehingga menyebabkan energi akan tersimpan di induktor. Saat saklar mosfet terbuka (toff), arus induktor ini akan mengalir menuju beban melewati dioda sehingga energi yang tersimpan di induktor akan menurun [8].

Untuk mengetahui besar nilai tegangan keluaran dari boost converter konvensional berdasarkan pengaruh perubahan duty cycle dapat dihitung sebagai berikut :

$$
v_{\text {out }}=\left(\frac{v}{1-D}\right)
$$

dimana [V] adalah tegangan keluaran, $v$ [V] adalah tegangan masukkan, dan $D$ adalah duty cycle.

\section{METODE PENELITIAN}

Kendaraan listrik membutuhkan rangkaian penaik tegangan untuk mencatu MAS yang digunakan. Namun rasio tegangan keluaran dari boost coverter kurang optimal untuk mencatu MAS, oleh karena itu digunakan rangkaian penaik tegangan dengan menggunakan metode Multilevel Boost Converter (MBC). Multilevel Boost Converter adalah sebuah konverter $\mathrm{dc}-\mathrm{dc}$ berbasis Pulse width Modulation (PWM) yang mengkombinasikan antara konveter boost konvensional dan fungsi switched capacitor untuk menghasilkan tegangan keluaran yang berbeda dan stabil dengan hanya menggunakan 1 driven switch, 1 induktor, $2 \mathrm{~N}-1$ dioda dan $2 \mathrm{~N}-1$ kapasitor.

$\mathrm{N}$ yang dimaksud adalah jumlah tingkat pada konverter boost multilevel [1]. Konverter ini dibangun dengan beberapa level yang dapat ditambah tanpa memodifikasi atau mengubah rangkaian utama serta dapat menggunakan frekuensi switching yang tinggi. Rangkaian multilevel boost konverter ditunjukkan pada Gambar 1. 


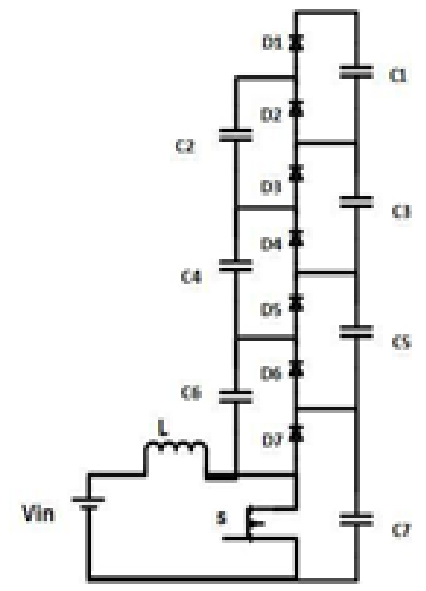

Gbr 1. Rangkaian Multilevel Boost Converter

Karakteristik ini dapat tercapai berkat pengalian pada tegangan keluaran konverter boost konvensional yang dikendalikan hanya dengan satu saklar yang ada di dalam konverter. Sehingga didapatkan nilai tegangan keluaran multilevel boost converter sebagai berikut.

$$
v_{\text {out }}=v_{\text {in }}\left(\frac{1}{1-D}\right) x N
$$

dimana $N$ adalah jumlah tingkatan dari topologi multilevel boost converter.

Dari Gambar 1 arus induktor pada rangkaian multilevel boost converter nilainya sama dengan arus masukannya. Maka arus rata-rata induktor dapat dihitung sebagai berikut.

$$
i_{l}=\left(\frac{N^{2} v_{c}}{(1-D) \text { Rout }}\right)
$$

dimana [A] adalah arus induktor, [V] adalah tegangan kapasitor, dan Rout [ohm] adalah tahanan beban. Induktansi induktor pada multilevel boost converter mempunyai nilai yang lebih rendah dibanding dengan boost converter konvensional. Nilai dari induktor tersebut dapat dicari sebagai berikut.

$$
L_{\min }=\frac{10 \times(1-D)^{2} R}{2 \times N^{2}} \times D \times T
$$

dimana [Henry] adalah induktansi induktor minimal dan $T$ adalah periode.
Sedangkan ripple tegangan dari multilevel boost converter dapat dihitung sebagai berikut.

$$
\begin{gathered}
\Delta v_{o}=\frac{v_{o} \times D}{f \times C \times R} \\
\Delta v_{o}=\frac{i_{o} \times D}{f \times C}
\end{gathered}
$$

dimana [V] adalah tegangan ripple, $f[\mathrm{~Hz}]$ adalah frekuensi, [A] adalah arus keluaran, dan $C$ [Farad] adalah kapasitansi kapasitor. Maka untuk menentukan nilai kapasitor dari multilevel boost converter adalah sebagai berikut.

$$
C=\frac{i_{o} \times D}{f \times \Delta v_{o}}
$$

\section{HASIL DAN PEMBAHASAN}

\section{A. Perangkat Boost Converter}

Penelitian ini menggunakan boost converter untuk membandingkan hasil antara boost converter konvensional dengan multilevel boost converter. Perbandingan data yang diambil yaitu tegangan keluaran saat diberikan beban resistif yang bervariasi dan juga perbandingan kecepatan putar MAS tanpa beban. Spesifikasi boost converter yang digunakan yaitu memiliki tegangan masukkan $12 \mathrm{~V}$, ripple arus sebesar 1 $\mathrm{A}$, dan ripple tegangan $1 \mathrm{~V}$. Gambar 2 merupakan perangkat boost converter yang akan digunakan sebagai data pembanding pada penelitian ini.

\section{B. Perancangan Multilevel Boost Converter}

Pada penelitian ini perangkat yang digunakan sebagai catu daya MAS merupakan multilevel boost converter dengan jumlah tingkatan yaitu tiga tingkat. Untuk menentukan nilai dari tiap komponen maka diperlukan beberapa parameter, yaitu tegangan masukkan $12 \mathrm{~V}$, tegangan keluaran $200 \mathrm{~V}$, frekuensi switching $5 \mathrm{kHz}$,arus keuaran 1.3 A, dan tegangan ripple $2 \mathrm{~V}$. Berdasarkan parameter di atas kemudian dilakukan perhitungan menggunakan persamaan yang terdapat pada bab III, maka didapatkan nilai duty cycle sebesar 0.82 , induktor sebesar 0.44 $\mathrm{mH}$, dan nilai kapasitor sebesar $106 \mu \mathrm{F}$ namun karena ketersedian kapasitor yang ada dipasaran 
besarnya lebih kecil dari nilai tersebut, maka digunakan kapasitor yang lebih besar dari nilai tersebut yaitu sebesar $150 \mu \mathrm{F}$. Gambar 3 merupakan realisasi dari perancangan.

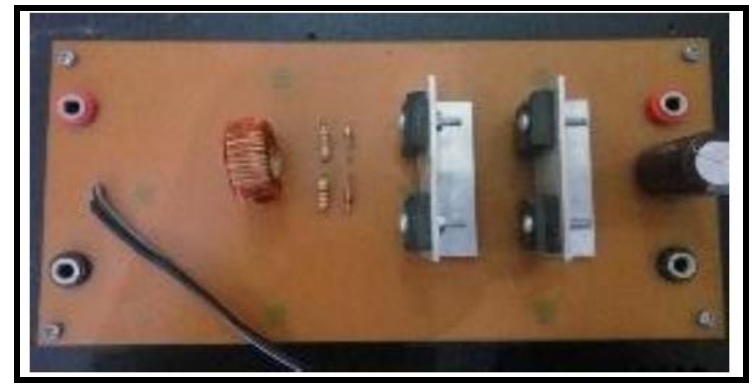

Gbr 2. Perangkat Boost Converter

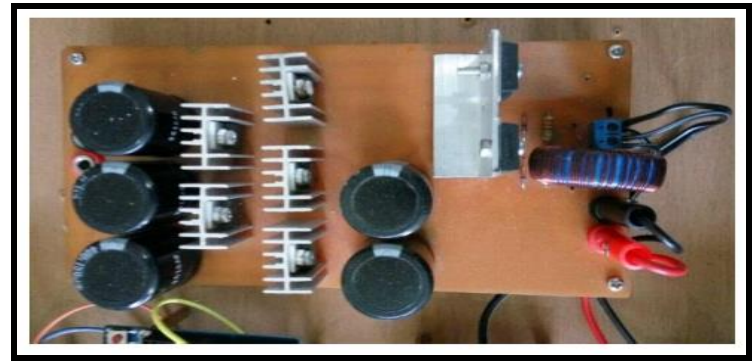

Gbr 3. Perangkat Multi Level Boost Converter

\section{C.Pengujian Perangkat Dengan Beban Resistif}

Pengujian ini berguna untuk mendapatkan perbandingan data pengaruh perubahan beban resisif terhadap tegangan keluaran antara perangkat boost converter konvensional dengan multilevel boost converter. Nilai duty cycle yang diberikan sama yaitu 20\%. Hasil pengujian yang didapatkan pada pembebanan resistif yaitu berupa nilai tegangan keluaran yang akan dibandingkan dengan tegangan keluaran berdasarkan teori.

Berdarsarkan data dari tabel 1 dan 2, tegangan keluran dari kedua perangkat mengalami peningkatan saat beban resistif yang digunakan semakin besar. Hal ini mengacu pada persamaan antara tegangan, arus dan hambatan. Ketika nilai resistansi semakin besar maka tegangan keluarannya akan semakin besar. Namun tegangan keluaran dari perangkat multilevel boost converter lebih besar dibandingkan dengan boost converter konvensional pada nilai beban yang sama. Maka dengan pengujian ini membuktikan bahwa topologi multilevel boost converter dapat menaikkan tegangan masukkan lebih besar dibanding rangkaian boost converter.
D. Pengaruh Perubahan Duty Cycle Terhadap Tegangan Keluaran dan Putaran MAS

Pengujian ini dilakukan dengan memberikan pulsa yang memiliki nilai duty cycle yang besarnya 10\%-60\%

Tabel 1. Pengujian Boost Converter dengan Beban Resistif

\begin{tabular}{cccccc}
\hline $\begin{array}{c}\mathrm{R} \\
(\mathrm{ohm})\end{array}$ & $\begin{array}{c}\text { Vin } \\
(\mathrm{V})\end{array}$ & $\begin{array}{c}\text { Vo } \\
\text { Ukur } \\
(\mathrm{V})\end{array}$ & $\begin{array}{c}\text { Vo } \\
\text { Hitung } \\
\text { (V) }\end{array}$ & $\begin{array}{c}\text { lin } \\
(\mathrm{A})\end{array}$ & $\begin{array}{c}\text { Iout } \\
(\mathrm{A})\end{array}$ \\
\hline 40 & 11,7 & 14,5 & 15,25 & 0,665 & 0,318 \\
160 & 11,8 & 25,2 & 15,25 & 0,52 & 0,15 \\
280 & 12 & 31,4 & 15,25 & 0,508 & 0,107 \\
340 & 12 & 32,4 & 15,25 & 0,437 & 0,097 \\
460 & 12,1 & 36,4 & 15,25 & 0,414 & 0,08 \\
570 & 12,2 & 41,3 & 15,25 & 0,435 & 0,073 \\
670 & 12,2 & 44,5 & 15,25 & 0,457 & 0,068 \\
\hline
\end{tabular}

Tabel 2. Pengujian Multi Boost Converter dengan Beban Resistif

\begin{tabular}{cccccc}
\hline $\begin{array}{c}\mathrm{R} \\
\text { (ohm) }\end{array}$ & $\begin{array}{c}\text { Vin } \\
(\mathrm{V})\end{array}$ & $\begin{array}{c}\text { Vo } \\
\text { Ukur } \\
(\mathrm{V})\end{array}$ & $\begin{array}{c}\text { Vo } \\
\text { Hitung } \\
\text { (V) }\end{array}$ & $\begin{array}{c}\text { Iin } \\
(\mathrm{A})\end{array}$ & $\begin{array}{c}\text { Iout } \\
(\mathrm{A})\end{array}$ \\
\hline 40 & 11,8 & 25,7 & 45,75 & 1,944 & 0,484 \\
160 & 11,9 & 39,5 & 45,75 & 1,105 & 0,229 \\
280 & 12 & 47,3 & 45,75 & 0,920 & 0,163 \\
340 & 12,1 & 50,2 & 45,75 & 0,846 & 0,149 \\
460 & 12,2 & 55,6 & 45,75 & 0,825 & 0,120 \\
570 & 12,2 & 61,4 & 45,75 & 0,753 & 0,103 \\
670 & 12,3 & 67,2 & 45,75 & 0,716 & 0,092 \\
\hline
\end{tabular}

Perangkat boost converter konvensional dan multilevel boost converter akan dihubungkan dengan MAS jenis seri dimana data dari pengujian ini ditunjukkan pada Tabel 3 dan 4. Untuk mengetahui perbandingan hasil pengujian, maka dibuatlah kurva hasil pengujian multilevel boost converter terhadap kurva karakteristik dari hasil pengujian boost converterpada Gambar 4 dan 5. Berdasarkan kurva dari Gambar 5 dapat dilihat bahwa kecepatan putar motor 
pada multilevel boost converter lebih tinggi yang disebabkan oleh tegangan keluaran yang lebih besar jika dibandingkan dengan hasil tegangan keluaran pada boost converter.

Hal ini membuktikan bahwa dengan menggunakan teknik multilevel boost converter dapat menghasilkan tegangan keluaran yang jauh lebih besar dibandingkan dengan tegangan masukkannya sehingga dapat mengendalikan putaran motor dengan kecepata yang lebih tinggi.

Tabel 3. Pengujian Boost Converter dengan Beban MAS

\begin{tabular}{cccccc}
\hline $\begin{array}{c}\mathrm{D} \\
(\%)\end{array}$ & $\begin{array}{c}\text { Vin } \\
(\mathrm{V})\end{array}$ & $\begin{array}{c}\text { Iin } \\
(\mathrm{A})\end{array}$ & $\begin{array}{c}\text { Vo } \\
(\mathrm{V})\end{array}$ & $\begin{array}{c}\text { Iout } \\
(\mathrm{A})\end{array}$ & $\begin{array}{c}\text { Putaran } \\
\text { Motor } \\
(\mathrm{rpm})\end{array}$ \\
\hline 10 & 12.3 & 0.208 & 26.7 & 0.046 & 0 \\
20 & 12.3 & 0.395 & 39.4 & 0.067 & 0 \\
30 & 12.2 & 0.693 & 58.6 & 0.079 & 200 \\
40 & 12.1 & 1.027 & 78.1 & 0.086 & 500 \\
50 & 12.1 & 2.022 & 99.7 & 0.092 & 800 \\
60 & 11.9 & 2.621 & 117.3 & 0.095 & 1100 \\
\hline
\end{tabular}

Tabel 4. Pengujian Multi Boost Converter dengan Beban MAS

\begin{tabular}{cccccc}
\hline $\begin{array}{c}\mathrm{D} \\
(\%)\end{array}$ & $\begin{array}{c}\text { Vin } \\
(\mathrm{V})\end{array}$ & $\begin{array}{c}\text { Iin } \\
(\mathrm{A})\end{array}$ & $\begin{array}{c}\text { Vo } \\
(\mathrm{V})\end{array}$ & $\begin{array}{c}\text { Iout } \\
(\mathrm{A})\end{array}$ & $\begin{array}{c}\text { Putaran } \\
\text { Motor } \\
(\mathrm{rpm})\end{array}$ \\
\hline 10 & 12.3 & 0.422 & 53.3 & 0.068 & 0 \\
20 & 12.3 & 0.705 & 80.3 & 0.08 & 320 \\
30 & 12.2 & 0.143 & 112 & 0.092 & 700 \\
40 & 12.1 & 1.712 & 147 & 0.104 & 1200 \\
50 & 12.1 & 2.429 & 184 & 0.112 & 1800 \\
60 & 11.9 & 3.257 & 202 & 0.114 & 2100 \\
\hline
\end{tabular}

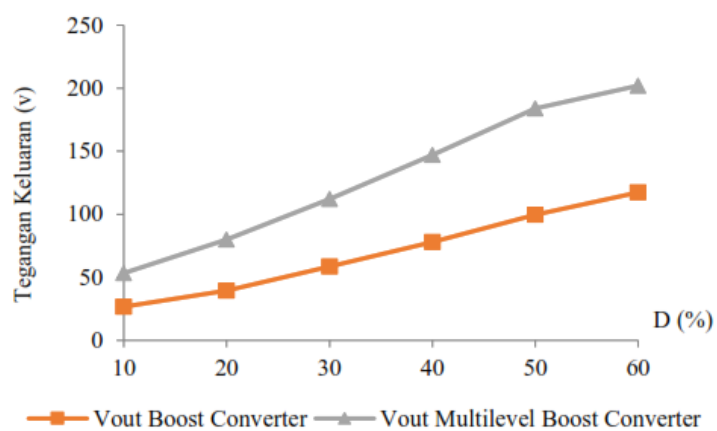

Gbr 4. Perbandingan D-Vo Kedua Perangkat

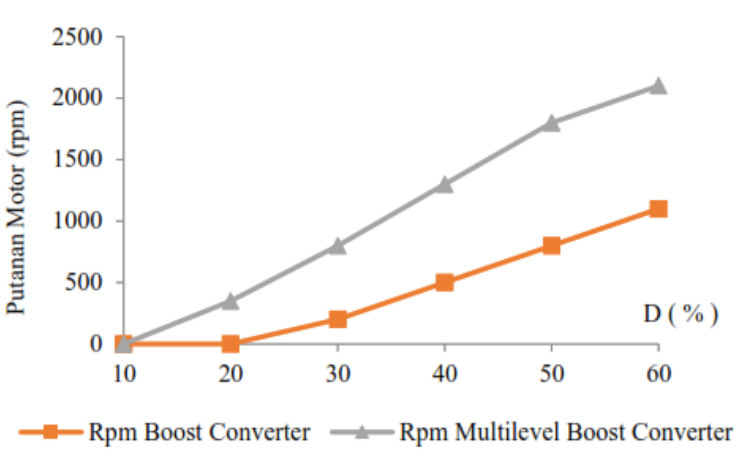

Gbr 5. Perbandingan D-Rpm Kedua Perangkat

\section{E. Pengujian Multilevel Boost Converter dengan MAS yang Bebannya Bervariasi}

Untuk mengetahui keberhasilan dari rangkaian alat multilevel boost converter yang digunakan sebagai catu daya MAS perlu dilakukan pengujian secara keseluruhan. Pada pengujian ini akan dilakukan pengujian motor arus searah dengan beban yang bervariasi. Variasi beban yang akan digunakan yaitu besi seberat $0,500,1500$, dan 2500 gram yang akan dikopel pada motor. Berikut merupakan realisasi dari perangkat multilevel boost converter yang digunakan untuk catu daya MAS. Pengujian dilakukan dengan memberikan variasi nilai duty cycle (D) pada rangkaian multilevel boost converter sebesar 10-60 \% yang mana tegangan keluaran dari rangkaian multilevel boost converter untuk mencatu MAS seri dengan beban yang bervariasi. Setelah dilakukan pengujian maka dihasilkan nilai tegangan dan arus keluaran dari rangkaian serta nilai putaran MAS. Data perbandingan tegangan dan arus keluaran pada beban 0, 500, 1500, dan 2500 gram akan digambarkan pada Gambar 7 dan 8 . Pembebanan yang bervariasi pada pengujian perangkat keras multilevel boost converter sangat mempengaruhi nilai keluaran arus dan tegangannya. Perbandingan tersebut akan terlihat saat beban MAS semakin bertambah maka nilai tegangan keluaran akan semakin menurun. Sedangkan arus keluaran perangkat keras akan semakin besar seiring bertambahnya beban pada MAS namun tidak terlalu signifikan. 


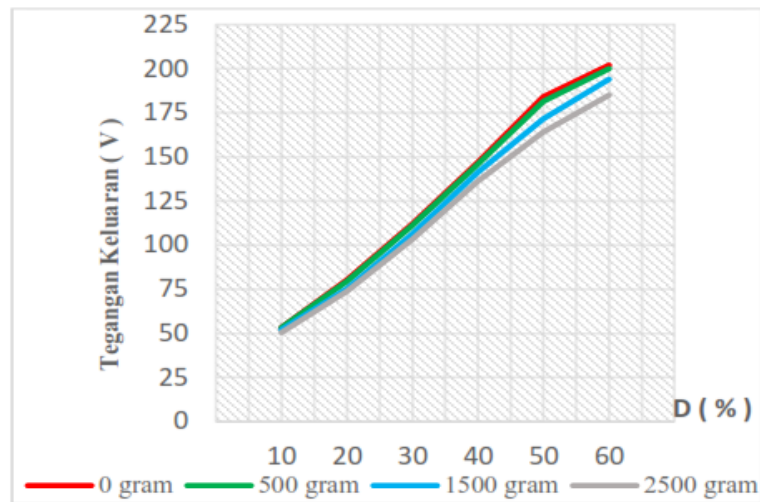

Gbr 6. Perbandingan Vo terhadap Variasi Beban pada MAS

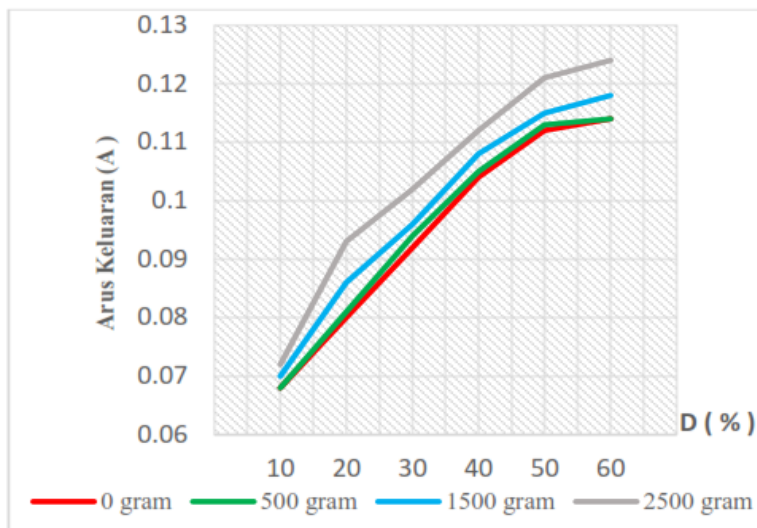

Gbr 7. Perbandingan Io terhadap Variasi Beban pada MAS

Peningkatan nilai arus ini adalah karena meningkatnya nilai torsi yang dibutuhkan saat beban MAS semakin berat. Selain nilai arus berubah, tegangan keluaran juga berubah saat beban semakin berat.

Berdasarkan persamaan daya maka semakin besar arus maka tegangannya akan semakin kecil. Sehingga saat beban semakin berat maka tegangan keluarannya semakin kecil. Pembebanan yang bervariasi pada pengujian perangkat keras multilevel boost converter sangat mempengaruhi nilai putaran dan torsi MAS.

Perbandingan tersebut akan terlihat saat beban MAS semakin bertambah maka putaran akan semakin menurun. Sedangkan torsi MAS akan semakin meningkat seiring bertambahnya beban pada MAS pada pengujian titik nilai duty cycle yang sama. Pada pembahasan ini, analisa menggunakan kurva karakteristik yaitu kurva yang menunjukkan perbandingan karakteristik hubungan antara torsi dan putaran MAS pada saat beban 0, 500, 1500 dan 2500 gram yang ditunjukkan pada Gambar 8.

Kemudian dibuat juga kurva karakteristik hubungan antara torsi dan arus jangkar dengan pengaruh beban $0,500,1500$ dan 2500 gram pada pengujian duty cycle $20 \%$ yang ditunjukkan pada Gambar 9.

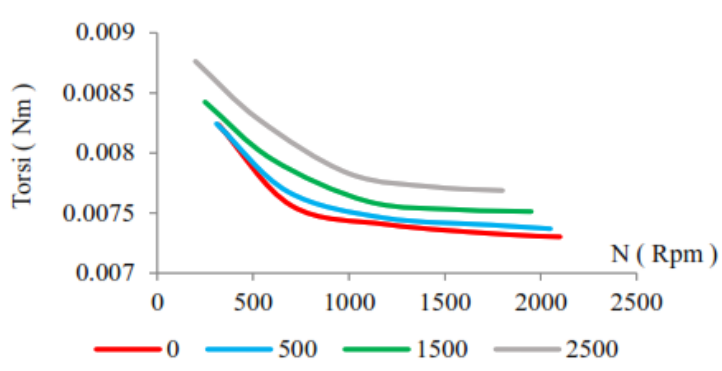

Gbr 8. Karakteristik T dan $\mathrm{N}$ terhadap Variasi Beban

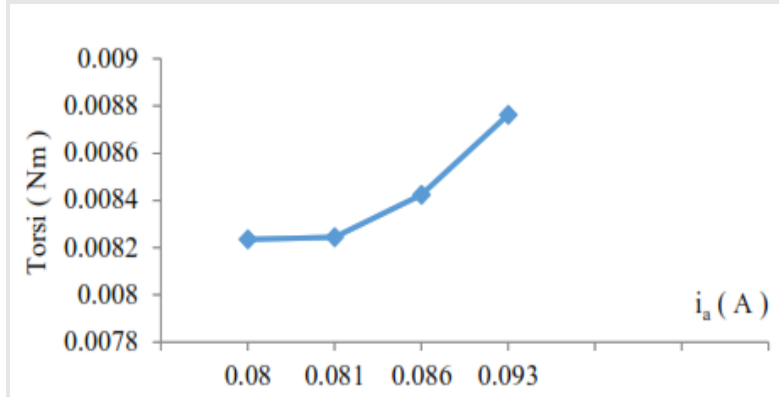

Gbr 9. Perbandingan T dan Ia terhadap Variasi Beban pada Duty Cycle 20\%

\section{KESIMPULAN}

Penelitian ini telah menghasilkan perangkat multilevel boost converter 3 tingkat yang digunakan sebagai catu daya MAS. Perangkat keras telah mampu digunakan sebagai catu daya MAS untuk kendaraan listrik karena dapat menaikkan tegangan baterai dengan rasio yang tinggi dimana pada duty cycle $60 \%$ tegangan keluaran mencapai 202 V. Multilevel boost converter juga dapat mengoperasikan MAS lebih baik dibanding converter boost konvensioanal dimana kecepatan putar motor pada multilevel boost converter lebih tinggi yang disebabkan oleh nilai tegangan keluaran yang lebih besar. Pada perangkat keras multilevel boost converter saat kenaikan beban yang dikopel dengan MAS maka terjadi kenaikan arus keluaran sedangkan tegangan motornya semakin berkurang. 


\section{REFERENSI}

[1] F. Y. Zaky, A. Muhammad, Y. Teguh, "Desain dan Simulasi Konverter Boost Multilevel sebagai Catu Daya Kendaraan Listrik", Jurnal Teknik POMITS Voll. 3, ISSN 23373539, 2014.

[2] Priowirjanto, Gator. "Prinsip Dasar Arus Searah" Direktorat Pendidikan Menengah Kejuruan, Jakarta 89-104, 2003.

[3] M.A. Zumain, "Prototipe Mobil Listrik dengan Menggunakan Motor DC Magnet Permanen 0,37 HP”. Fakultas Tenik Universitas Indonesia, Depok, 9-10, 2009.

[4] S. Nur, S. Erwin, K. Ekki. "Perancangan dan Implementasi Konverter untuk Pembangkit Listrik Hybrid Tenaga Surya dan Angin untuk Suplai Listrik Arus Bolak Balik", Fakultas Teknik Universitas Telkom, Bandung, 20, 2015.

[5] P. Thounhong, B. Davat. "Study of A Multhiphase Interleaved Step-Up Converter for Fuel Cell High Power
Applications", Energy Conversion and Management 51, 826-862, 2010.

[6] I. Joni, W. Slamet, Mustaziri. "Rancang Bangun Alat Pemberi Pakan Burung Otomatis Berbasis Mikrokontroler Atmega16 dengan SMS Gateway", Politeknik Negeri Sriwijaya, Palembang, 2014.

[7] Rectifier, International. "High and Low Side Driver, All High Voltage Pins on One Side, Separate Logic and Power Ground, Shut-Down in a 14pin DIP package".

[8] M. Ganta, P. Nirupa, T. Akshitha, R. Seyezhai. "Design and Simulation of PWM FED Two Phase Interleaved Boost Converter Jurnal Rekayasa Elektrika Vol. xx, No. xx, April 2 for Renewable Energy Source", International Journal of Electtrical and Data Communication, Vol. 1, Issue 1, ISSN: 2320-2084, 2013.

[9] R Caro, Julio, Ramirez, Juan, Peng, Valderrabano, "A DC- DC Multilevel Boost Converter", IET Power Electron, Vol.3, Iss.1, 129-137, 2010. 